\title{
ANALISIS PENGAKUAN PENDAPATAN PADA PERUSAHAAN KONSTRUKSI
}

\author{
Oleh : \\ Elmira Febri Darmayanti \\ Email : efdarmayanti@gmail.com \\ Fakultas Ekonomi, Universitas Muhammadiyah Metro
}

\begin{abstract}
Most companies aim to maximize profit or gain. Therefore, one element of which is related to the size of the profit generating companies is revenue. In the construction company, there are two methods of revenue recognition are completed contract method and the percentage of completion method. The purpose of this research is to find out which kind of method that is suitable for Nolimax Jaya Ltd. Co. The analytical method used is descriptive method that describes a situation objectively. Data collected by observation, interviews, and used documentation and literature are relevant to this research.The survey revealed that the company used the percentage of completion method with physical progress approach. Based on the result, the company recognized a higher income or overstatement when compared with the cost to cost approach. The cost to cost approach provide a more reasonable because it recognizes revenue based on costs incurred that reflect the completion stage in the current period and in accordance with the matching principle and the principle of conservatism in financial statement presentation.
\end{abstract}

Keyword: Revenue recognition, physical progress approach, and cost to cost approach.

\section{PENDAHULUAN}

\section{LATAR BELAKANG PENELITIAN}

Pertumbuhan ekonomi global saat ini semakin tak menentu dan persaingan di dunia usaha pun semakin banyak. Salah satu perusahaan yang terkena dampak krisis global adalah perusahaan yang bergerak dalam bidang kontruksi. Karena semakin banyak perusahaan sejenis yang menawarkan produk yang sama dengan persaingan harga dan fasilitas yang berbeda. Sehingga manajemen perusahaan perlu mengambil langkah-langkah dan kebijakan yang dibutuhkan untuk pengambilan keputusan dan strategi yang tepat dalam mempertahankan kelangsungan hidup, melakukan ekspansi, serta meningkatkan profitabilitas perusahaan. 
Salah satu informasi yang sangat penting dalam pengambilan keputusan tersebut adalah informasi akuntansi, yaitu mengenai posisi keuangan, hasil operasi, atau kinerja serta perubahan posisi keuangan perusahaan, karena informasi ini dapat digunakan oleh pihak internal maupun eksternal. Dari posisi laporan keuangan dapat diketahui biaya-biaya yang dikeluarkan dalam proses pembangunan konstruksi dari tahap perencanaan sampai akhir proses konstruksi.

Keputusan dalam penetapan harga jual yang tepat sangat mempengaruhi target yang telah ditetapkan oleh perusahaan sebagai upaya untuk meningkatkan profitabilitas dan dapat mempengaruhi kelangsungan hidup perusahaan. Penentuan harga jual dilakukan secara kontinyu dan selalu dievaluasi serta disesuaikan dengan kondisi yang sedang dihadapi perusahaan. Perubahan harga jual mempunyai tujuan untuk menyesuaikan agar harga baru yang ditetapkan mencerminkan biaya saat ini (current cost) atau biaya masa depan (future cost), return yang diinginkan oleh perusahaan, reaksi pesaing, dan sebagainya. (Supriyono:2011) Penetapan harga jual produk perusahaan harus menjadi kebijakan yang benar-benar dipertimbangkan secara matan dan terintegrasi. (Rudianto:2013)

Selain penetapan harga jual, pengakuan pendapatan juga termasuk hal terpenting dalam perusahaan konstruksi, karena pendapatan merupakan salah satu elemen dalam laporan keuangan yang bersifat material. Pendapatan adalah hasil penjualan barang dan jasa yang dibebankan kepada langganan/mereka yang menerima. (Sofyan Syafri Harahap:2011)

\section{PERMASALAHAN}

Penetapan harga jual yang salah dapat berakibat fatal dalam masalah keuangan perusahaan, karena menimbulkan kerugian yang dapat mempengaruhi kontinyuitas usaha perusahaan konstruksi. Metode pengakuan pendapatan dalam perusahaan konstruksi ada dua, yaitu metode kontrak selesai dan metode persentase penyelesaian. (Rangkuti:2008) dalam Smith and Skousen. Pada metode kontrak selesai mengakui pendapatan dan laba kotor pada saat kontrak diselesaikan secara keseluruhan. Sedangkan dalam metode persentase penyelesaian mengakui pendapatan, biaya, dan laba kotor sesuai dengan persentase pekerjaan yang diselesaikan dalam tiap periode.

Dengan adanya perbedaan dalam metode pengakuan pendapatan berdasarkan persentase penyelesaian pekerjaan tiap periode, maka perusahaan dihadapkan pada permasalahan bagaimana menentukan pengakuan pendapatan yang tepat terutama pada proyek-proyek jangka panjang, sehingga laporan keuangan dapat disajikan secara wajar sesuai dengan kinerja perusahaan pada periode tersebut.

\section{BATASAN MASALAH}

Batasan masalah dalam penelitian ini adalah:

a. Bagaimana penentuan harga jual pada PT. Nolimax Jaya? 
b. Bagaimana penerapan pengakuan pendapatan dengan menggunakan metode persentase penyelesaian dalam rangka penyajian laporan keuangan pada PT. Nolimax Jaya?

\section{TUJUAN PENELITIAN}

Tujuan dalam penelitian ini adalah untuk mengetahui:

a. Penentuan harga jual PT. Nolimax Jaya

b. Penerapan pengakuan pendapatan dengan menggunakan metode persentase penyelesaian dalam rangka penyajian laporan keuangan pada PT. Nolimax Jaya

\section{KAJIAN TEORITIK}

\section{HARGA JUAL}

Mulyadi (2005) mendefinisikan harga jual adalah harga yang dapat menutup semua biaya (biaya produksi dan non-produksi) ditambah dengan laba yang wajar, umumnya biaya tidak menentukan harga jual produk atau jasa.

Krismiaji dan Anni (2011) menyatakan harga jual adalah upaya untuk menyeimbangkan keinginan untuk memperoleh manfaat sebesar-besarnya dari perolehan pendapatan yang tinggi dan penurunan volume penjualan jika harga jual yang dibebankan ke konsumen terlalu mahal.

\section{PENDAPATAN}

Menurut Sofyan Syafri Harahap (2011) mengemukakan bahwa pendapatan adalah hasil penjualan barang dan jasa yang dibebankan kepada langganan/mereka yang menerima.

Menurut PSAK No. 23 (2015) pendapatan adalah arus kas bruto dari manfaat ekonomi yang timbul dari aktivitas normal entitas selama satu periode jika arus tersebut mengakibatkan kenaikan ekuitas yang tidak berasal dari kontribusi penanaman modal.

Menurut Soemarso (2005) pendapatan merupakan peningkatan manfaat ekonomi selama satu periode akuntansi tertentu dalam bentuk pemasukan atau penambahan aktiva atau penurunan kewajiban yang mengakibatkan kenaikan ekuitas, yang tidak berasal dari kontribusi penanaman modal. Peningkatan jumlah aktiva atau penurunan kewajiban dapat berasal dari penyerahan barang/jasa atau aktivitas usaha lainnya dalam satu periode.

\section{PENGAKUAN PENDAPATAN}

Kieso (2010) menyatakan pengakuan pendapatan menetapkan bahwa pendapatan diakui pada saat:

1. Direalisasi atau dapat direalisasi

Pendapatan direalisasi apabila barang dan jasa ditukar dengan kas atau klaim atas kas (piutang). Pendapatan dapat direalisasi apabila aktiva yang diterima 
dalam pertukaran segera dapat dikonversi menjadi kas atau klaim atas kas dengan jumlah yang diketahui.

2. Dihasilkan

Pendapatan dihasilkan (earned) apabila entitas bersangkutan pada hakikatnya telah menyelesaikan apa yang seharusnya dilakukan untuk mendapat hak atas manfaat yang dimiliki oleh pendapatan itu.

\section{PENGAKUAN PENDAPATAN KONSTRUKSI}

Dalam PSAK No. 34 (2010) pengakuan pendapatan dan biaya kontrak yaitu jika hasil kontrak kontruksi dapat diestimasi secara andal, maka pendapatan kontrak yang berhubungan dengan kontrak diakui masing-masing sebagai pendapatan dan beban dengan memperhatikan tahap penyelesaian aktivitas kontrak pada tanggal akhir priode pelaporan, taksiran rugi pada kontrak kontruksi segera diakui sebagai beban.

Menurut Rangkuti (2008) dalam Smith and Skousen, ada 2 metode dalam pengakuan pendapatan jasa konstruksi, yaitu:

1. Metode Kontrak Selesai (Completed Contract Method)

Metode ini biasanya digunakan oleh perusahaan yang mempunyai kontrak jangka pendek atau proyek yang memiliki resiko yang tidak dapat diestimasi secara andal. Metode kontrak selesai mengakui pendapatan dan laba kotor pada saat kontrak diselesaikan secara keseluruhan.

2. Metode Persentase Penyelesaian (Percentage of Completion Method)

Metode ini biasanya digunakan oleh perusahaan yang memiliki kontrak jangka panjang, dimana jangka waktunya lebih dari satu periode akuntansi. Metode ini mencerminkan prestasi kerja masa berjalan atas penyelesaian kontrak lebih dari satu periode akuntansi. Metode ini mengakui pendapatan biaya dan laba kotor sesuai dengan tercapainya kemajuan ke arah penyelesaian kontrak jangka panjang.

Metode persentase penyelesaian memiliki dua pendekatan, yaitu:

a. Metode pendekatan fisik (physical progress approach) adalah metode pengakuan pendapatan yang diukur berdasarkan persentase kemajuan fisik yang dicapai di lapangan. Dengan pendekatan fisik ukuran dibuat berdasarkan hasil yang telah dicapai (output measures).

b. Metode pendekatan cost-to-cost adalah metode pengakuan pendapatan yang diukur berdasarkan persentase selesai yang diperoleh dari besarnya biaya yang terjadi untuk mencapai tahap penyelesaian pekerjaan proyek. Perhitungannya berdasarkan ukuran masukan (input measures), yaitu usahausaha dan biaya-biaya yang dikeluarkan dalam pelaksanaan pekerjaan suatu kontrak. Metode upaya/usaha yang dikeluarkan (efforts-expended method). Metode ini menentukan persentase penyelesaian atas pelaksanaan pekerjaan proyek dengan cara membandingkan usaha-usaha yang telah tercurah dengan usaha-usaha yang dibutuhkan untuk menyelesaikan proyek.

Definisi ini diperkuat dengan pendapat Stice (2007) yang menyatakan bahwa metode upaya yang dikeluarkan didasarkan pada beberapa ukuran atas pekerjaan yang telah dilakukan. Ukuran-ukuran tersebut meliputi jam tenaga kerja, dolar tenaga kerja, jam mesin atau jumlah bahan baku. Tingkat penyelesaian diukur 
dengan cara yang serupa seperti metode cost to cost: rasio dari usaha yang telah dilakukan sampai tanggal tersebut terhadap estimasi total usaha yang masih harus dilakukan untuk seluruh kontrak pekerjaan dalam pelaksanaan.

\section{BIAYA DAN BEBAN}

Menurut Mulia (2007) biaya (cost) adalah kas atau nilai ekuivalen kas yang dikorbankan atau dikonsusmsi untuk mendapatkan barang dan jasa yang diharapkan memberi manfaat saat ini atau masa mendatang. Sedangkan beban (expense) dapat didefinisikan sebagai arus keluar barang atau jasa, yang akan dibebankan pada atau ditandingkan (matched) dengan pendapatan untuk mendapatkan laba (income). Beban mencakup semua biaya yang telah habis dipakai (expired) yang dapat dikurangkan dari pendapatan.

Ratunuman dalam Harahap (2013) mendefinisikan beban sebagai arus keluar aktiva, penggunaan aktiva, atau munculnya kewajiban atau kombinasi keduanya atau selama periode yang disebabkan oleh pengiriman barang, pembuatan barang atau pembuatan jasa, atau pelaksanaan kegiatan lainnya yang merupakan kegiatan utama perusahaan.

\section{PRINSIP PENANDINGAN (The Matching Principle)}

Prinsip penandingan menganggap bahwa beban harus diakui dalam periode yang sama dengan satu kesatuan dengan pendapatan. Belkaoui (2006) menyatakan bahwa hubungan antara pendapatan dan beban dalam proses menandingkan tergantung pada salah satu dari 4 (empat) kriteria berikut:

1. Penandingan langsung yang telah terpakai (expired cost) dengan suatu pendapatan (misalnya harga pokok penjualan dikaitkan dengan penjualan terkait).

2. Penandingan langsung dari beban yang telah terpakai pada periode tersebut (misalnya gaji karyawan untuk periode tersebut)

3. Alokasi beban sepanjang periode yang memperoleh manfaat (misalnya depresiasi)

4. Menjadikan beban semua biaya lain dalam periode terjadinya, kecuali jika dapat ditunjukan bahwa biaya tersebut masih memiliki manfaat di masa mendatang.

\section{METODOLOGI PENELITIAN}

\section{PENDEKATAN PENELITIAN}

Penelitian ini menggunakan pendekatan deskriptif kualitatif yaitu suatu model penelitian yang berusaha untuk membuat gambaran/paparan dan menggali secara cermat serta mendalam tentang fenomena yang terjadi pada objek penelitian atau yang menjadi permasalahan dalam penelitian, yaitu mengenai pengakuan pendapatan dengan menggunakan metode persentase penyelesaian. Penelitian difokuskan pada data tahun 2012 untuk proyek-proyek jangka panjang yang jangka waktunya lebih dari satu periode akuntansi. 
Pendapatan dan laba kotor konstruksi yang dihasilkan akan dibandingkan dengan menggunakan pendekatan physical progress dan pendekatan cost to cost, sehingga akan diketahui pendekatan mana yang paling sesuai untuk proyek konstruksi jangka panjang berdasarkan prinsip penandingan (the matching principle) dalam rangka penyajian laporan keuangan yang wajar bagi perusahaan.

\section{JENIS, SUMBER, DAN TEKNIK PENGUMPULAN DATA}

Data yang digunakan dalam penelitian ini adalah data primer dan data sekunder. Sugiono (2014) Data primer diperoleh dari pengamatan serta wawancara langsung dengan sumber yang berhubungan dengan objek yang diteliti, yaitu mengenai kebijakan akuntansi serta metode yang digunakan dalam setiap proyek konstruksi perusahaan. Wawancara dilakukan dengan pihak pengawas lapangan, site engineering manager (SEM), biro administrasi marketing, dan bagian akuntansi. Sedangkan data sekunder diperoleh dari dokumentasi/arsip perusahaan, laporan tahunan perusahaan, dan studi pustaka mengenai segala sesuatu yang relevan dengan penelitian ini, baik dari buku-buku, jurnal, maupun situs internet.

\section{TEKNIK ANALISIS DATA}

Teknik analisis yang digunakan dalam penelitian ini adalah sebagai berikut:

1. Mengklasifkasikan proyek jangka panjang beserta nilai kontrak yang disetujui dan jangka waktu pengerjaannya, mengidentifikasi persentase penyelesaian yang ditentukan dari physical progress, mengidentifikasi rencana anggaran biaya aktual yang dikeluarkan untuk selanjutnya digunakan dalam penentuan persentase selesai menurut metode cost to cost.

2. Melakukan perhitungan pendapatan dan laba periode berjalan dengan mencari selisih antara pendapatan kontrak periode berjalan dengan biaya proyek berjalan atau harga pokok konstruksi yang diakui dengan dua pendekatan yang terdapat pada metode persentase penyelesaian, yaitu pendekatan physical progress dan pendekatan cost to cost.

3. Membandingkan hasil perhitungan pendapatan dan laba periode berjalan yang diakui dengan pendekatan physical progress dan pendekatan cost to cost.

4. Melakukan analisis terhadap hasil perbandingan untuk menentukan pendekatan yang paling sesuai dengan proyek jangka panjang dalam rangka penyajian laporan keuangan yang wajar.

Sejalan dengan teori yang diuraikan diatas, Kieso (2007) memberikan rumus untuk perhitungan persentase penyelesaian dasar cost to cost:

Persentase penyelesaian $=\frac{\text { Biaya yang terjadi sampai tanggal ini }}{\text { Estimasi paling ak hir total biaya selesai }}$

Sedangkan untuk mengetahui jumlah pendapatan atau laba kotor yang akan diakui sampai tanggal ini:

Persentase penyelesaian 


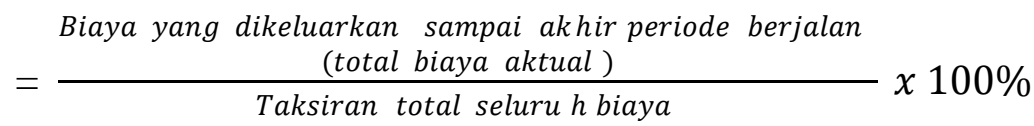

Untuk mengetahui jumlah pendapatan periode berjalan berdasarkan cost to cost: Pendapatan periode berjalan adalah selisih antara pendapatan yang diakui sampai tanggal ini dan pendapatan yang diakui dalam periode sebelumnya. Sedangkan untuk mengetahui pendapatan dan laba kotor setiap periode adalah selisih antara pendapatan atau laba kotor yang diakui sekarang dengan pendapatan atau laba kotor yang diakui pada periode sebelumnya.

\section{HASIL PENELITIAN DAN PEMBAHASAN}

\section{KEBIJAKAN AKUNTANSI PERUSAHAAN DALAM PENETAPAN HARGA JUAL}

Dalam penetapan harga jual perusahaan akan melakukan perhitungan terlebih dahulu mengenai estimasi biaya yang akan dikeluarkan, kemudian perusahaan akan menaksir jumlah laba yang bisa ditolelir. Pada praktiknya PT. Nolimax Jaya menggunakan metode persentase penyelesaian dalam mengakui pendapatan jangka panjang-nya, dimana semua biaya yang dikeluarkan untuk pembangunan dicatat dalam rekening bangunan dalam pelaksanaan, dan setiap akhir periode akan dilakukan perhitungan laba dan rugi berdasarkan persentase penyelesaian. Taksiran laba dicatat dengan mendebit pengakuan laba kontrak jangka panjang.

Tabel.1

Daftar Harga Jual Gedung PT. Nolimax Jaya Tahun 2012 (dalam rupiah)

\begin{tabular}{|c|c|c|c|c|c|c|}
\hline No & $\begin{array}{c}\text { Tipe } \\
\text { Bangunan }\end{array}$ & Harga Jual & $\begin{array}{c}\text { Realisasi } \\
\text { Biaya }\end{array}$ & $\begin{array}{c}\text { Taksiran } \\
\text { Biaya } \\
\text { Penyelesaian }\end{array}$ & Total Biaya & $\begin{array}{c}\text { Taksiran } \\
\text { Laba }\end{array}$ \\
\hline 1 & Standard & 55.800 .000 & 23.000 .000 & 22.000 .000 & 45.000 .000 & 5.520 .000 \\
\hline 2 & Menengah & 70.500 .000 & 27.000 .000 & 24.000 .000 & 51.000 .000 & 10.323 .000 \\
\hline 3 & Sudut & 94.500 .000 & 35.000 .000 & 28.000 .000 & 63.000 .000 & 17.500 .000 \\
\hline
\end{tabular}

Tabel.2

Daftar Harga Jual Gedung PT. Nolimax Jaya Tahun 2013 (dalam rupiah)

\begin{tabular}{|c|c|c|c|c|c|c|}
\hline No & $\begin{array}{c}\text { Tipe } \\
\text { Bangunan }\end{array}$ & Harga Jual & $\begin{array}{c}\text { Realisasi } \\
\text { Biaya }\end{array}$ & $\begin{array}{c}\text { Taksiran } \\
\text { Biaya } \\
\text { Penyelesaian }\end{array}$ & $\begin{array}{c}\text { Total } \\
\text { Biaya }\end{array}$ & $\begin{array}{c}\text { Taksiran } \\
\text { Laba }\end{array}$ \\
\hline 1 & Standard & 58.500 .000 & 25.000 .000 & 22.000 .000 & 47.000 .000 & 6.117 .000 \\
\hline 2 & Menengah & 75.500 .000 & 29.000 .000 & 25.000 .000 & 54.000 .000 & 11.546 .000 \\
\hline 3 & Sudut & 99.500 .000 & 37.000 .000 & 30.000 .000 & 67.000 .000 & 17.948 .000 \\
\hline
\end{tabular}

Dari tabel diatas dapat terlihat bahwa terjadi perubahan harga jual dari tahun 2012 dan 2013. Kebijakan perubahan harga ini mengindikasikan bahwa harga bangunan mengalami peningkatan. Kenaikan harga jual tersebut disebabkan oleh meningkatnya nilai NJOP dan biaya bahan baku yang akan digunakan dalam konstruksi. Harga jual yang ditentukan adalah harga jual yang didapat setelah memprediksi laba. Untuk penjualan, PT. Nolimax Jaya memberlakukan sistem 
cash bertahap, dimana pembayaran tahap pertama adalah 50\% dari harga jual, dan dianggap sebagai uang muka. (Biro Marketing PT. Nolimax Jaya, 2014)

\section{ANALISIS METODE PENGAKUAN PENDAPATAN YANG DITERAPKAN PERUSAHAAN}

Dalam kondisi existing, perusahaan menggunakan metode persentase penyelesaian dengan menggunakan physical progress dalam mengakui pendapatannya yang didasarkan pada hasil unit keluaran (output measures). Penilaian persentase bobot setiap kemajuan fisik merupakan hasil opname pekerjaan lapangan (proyek) yang dilakukan oleh pengawas lapangan bersama site engineering manager. Pengawas lapangan membuat laporan kemajuan fisik harian berdasarkan penyelesaian fisik yang telah dicapai, dan selanjutnya membuat laporan mingguan, kemudian dituangkan dalam laporan prestasi proyek. Setelah laporan prestasi proyek disetujui oleh site engineering manager, maka laporan prestasi proyek dilaporkan dalam laporan perkembangan pekerjaan yang telah diketahui dan disetujui oleh manager proyek dan pihak terkait.

Pencatatan pengakuan pendapatan dilakukan pada saat diterbitkan invoice dan laporan prestasi proyek atas pekerjaan kontrak dan ditanda-tangani oleh pihak pemberi kerja, sedangkan untuk pengakuan dan pencatatan beban yang berkaitan dengan proyek konstruksi dilakukan pada saat terjadinya atau pada saat terhutang atas masing-masing beban tersebut.

\section{Pengakuan Pendapatan dengan Pendekatan Physical Progress}

Perusahaan melakukan perhitungan pendapatan yang diakui pada periode yang bersangkutan dengan mengalikan persentase penyelesaian fisik yang sudah disetujui dengan nilai kontak bersih, kemudian hasilnya akan dicatat sebagai pendapatan atau penjualan konstruksi.

Tabel.3 Perhitungan Pendapatan Konstruksi Tahun 2012 (dalam rupiah)

\begin{tabular}{|c|c|c|c|c|}
\hline No & $\begin{array}{c}\text { Nama Proyek } \\
\text { Penjualan } \\
\text { Gedung }\end{array}$ & $\begin{array}{c}\text { Nilai Kontrak } \\
\text { sebelum PPN }\end{array}$ & $\begin{array}{c}\text { Progres Fisik } \\
\text { Tahun 2012 }\end{array}$ & $\begin{array}{c}\text { Pendapatan } \\
\text { yang Diakui }\end{array}$ \\
\hline 1 & A & 29.322 .727 & $34,15 \%$ & 10.013 .711 \\
\hline 2 & B & 31.032 .405 & $3,81 \%$ & 1.182 .334 \\
\hline 3 & $\mathrm{C}$ & 27.748 .571 & $100,00 \%$ & 27.748 .571 \\
\hline 4 & $\mathrm{D}$ & 15.290 .636 & $100,00 \%$ & 15.290 .636 \\
\hline 5 & $\mathrm{E}$ & 17.583 .354 & $100,00 \%$ & 17.583 .354 \\
\hline
\end{tabular}


Tabel. 4 Laba Kotor Konstruksi Tahun 2012 (dalam rupiah)

\begin{tabular}{|c|c|c|c|c|}
\hline No & $\begin{array}{c}\text { Nama Proyek } \\
\text { Penjualan } \\
\text { Gedung }\end{array}$ & $\begin{array}{c}\text { Pendapatan } \\
\text { yang Diakui }\end{array}$ & $\begin{array}{c}\text { Biaya Proyek } \\
\text { Berjalan (Aktual) }\end{array}$ & $\begin{array}{c}\text { Laba Kotor } \\
\text { Konstruksi }\end{array}$ \\
\hline 1 & $\mathrm{~A}$ & 10.013 .711 & 8.993 .141 & 1.020 .569 \\
\hline 2 & $\mathrm{~B}$ & 1.182 .334 & 1.041 .082 & 141.252 \\
\hline 3 & $\mathrm{C}$ & 27.748 .571 & 24.546 .107 & 3.202 .464 \\
\hline 4 & $\mathrm{D}$ & 15.290 .636 & 13.757 .605 & 1.533 .031 \\
\hline 5 & $\mathrm{E}$ & 17.583 .354 & 15.744 .256 & 1.839 .097 \\
\hline
\end{tabular}

Berdasarkan pada Tabel.3 dan Tabel. 4, dapat dijelaskan bahwa: nilai kontrak sebelum PPN adalah nilai kontrak yang diperoleh berdasarkan surat perjanjian kontrak kerja yang sudah disepakati oleh kedua belah pihak, dan progres fisik tahun 2012 merupakan hasil opname pekerjaan di lapangan yang ditentukan dalam bentuk persentase progres fisik. Pendapatan yang diakui merupakan hasil kali dari nilai kontrak sebelum PPN dengan persentase progres fisik. Biaya proyek berjalan merupakan biaya aktual selama pelaksanaan proyek untuk tahun 2012 baik berasal dari proyek maupun kantor cabang yang dicatat dan dikumpulkan oleh bagian akuntansi. Laba kotor konstruksi merupakan perhitungan dari selisih antara pendapatan yang diakui dengan biaya proyek berjalan.

\section{PEMBAHASAN}

Dalam pendekatan physical progress seringkali menyebabkan ketidaksesuaian perkiraan persentase penyelesaian menurut pengawas lapangan dan site engineering manager dengan perkiraan perusahaan karena tidak memperhatikan besarnya biaya yang terjadi atau usaha yang telah dicurahkan untuk mencapai tahap penyelesaian pekerjaan proyek dalam periode berjalan, sehingga menyebabkan pendapatan, beban, dan laba konstruksi yang dilaporkan tidak dapat diatribusikan menurut penyelesaian pekerjaan kontrak secara proporsional.

\section{PENGAKUAN PENDAPATAN DENGAN PENDEKATAN Cost to Cost}

Persentase penyelesaian diperoleh dari perbandingan biaya-biaya yang dikeluarkan selama periode berjalan terhadap taksiran jumlah seluruh biaya atau rencana anggaran biaya (RAB), diterapkan pada jumlah seluruh pendapatan atau taksiran seluruh laba kotor dalam kontrak, untuk mendapatkan jumlah pendapatan atau jumlah laba kotor yang diakui sekarang. Dalam menentukan RAB terdapat faktor dan variabel yang harus diperhatikan, diantaranya adalah mempertimbangkan tingkat fluktuasi harga bahan-bahan konstruksi, sehingga nilai $\mathrm{RAB}$ yang ditentukan sesuai dengan kebutuhan pengeluaran biaya dalam rangka penyelesaian proyek pada periode berjalan.

Dalam menghitung pengakuan pendapatan, proyek konstruksi yang telah selesai dikerjakan $100 \%$, maka taksiran total biaya penyelesaian atau RAB tidak 
diperlukan lagi sebagai perbandingan untuk menentukan persentase penyelesaian, tetapi sebagai gantinya yang digunakan adalah total biaya aktual yang dikeluarkan sebagai dasar perbandingan perhitungan.

Tabel.5 Perhitungan Persentase Penyelesaian Tahun 2012 (dalam rupiah)

\begin{tabular}{|c|c|c|c|c|c|}
\hline No & $\begin{array}{c}\text { Nama } \\
\text { Proyek } \\
\text { Gedung }\end{array}$ & $\begin{array}{c}\text { Nilai } \\
\text { Kontrak } \\
\text { sebelum } \\
\text { PPN }\end{array}$ & $\begin{array}{c}\text { RAB } \\
\text { Proyek }\end{array}$ & $\begin{array}{c}\text { Biaya Proyek } \\
\text { Berjalan } \\
\text { (Aktual) }\end{array}$ & $\begin{array}{c}\text { Persentase } \\
\text { Penyelesaian }\end{array}$ \\
\hline 1 & A & 29.322 .727 & 28.304 .985 & 8.993 .141 & $31,77 \%$ \\
\hline 2 & $\mathrm{~B}$ & 31.032 .405 & 27.985 .641 & 1.041 .082 & $3,72 \%$ \\
\hline 3 & $\mathrm{C}$ & 27.748 .571 & 24.546 .107 & 24.546 .107 & $100,00 \%$ \\
\hline 4 & $\mathrm{D}$ & 15.290 .636 & 13.757 .605 & 13.757 .605 & $100,00 \%$ \\
\hline 5 & $\mathrm{E}$ & 17.583 .354 & 15.744 .256 & 15.744 .256 & $100,00 \%$ \\
\hline
\end{tabular}

Tabel.6 Perhitungan Pengakuan Pendapatan Tahun 2012 (dalam rupiah)

\begin{tabular}{|c|c|c|c|c|}
\hline No & $\begin{array}{c}\text { Nama Proyek } \\
\text { Gedung }\end{array}$ & $\begin{array}{c}\text { Nilai Kontrak } \\
\text { sebelum PPN }\end{array}$ & $\begin{array}{c}\text { Persentase } \\
\text { Penyelesaian }\end{array}$ & $\begin{array}{c}\text { Pendapatan } \\
\text { yang Diakui }\end{array}$ \\
\hline 1 & $\mathrm{~A}$ & 29.322 .727 & $31,77 \%$ & 9.315 .830 \\
\hline 2 & $\mathrm{~B}$ & 31.032 .405 & $3,72 \%$ & 1.154 .405 \\
\hline 3 & $\mathrm{C}$ & 27.748 .571 & $100,00 \%$ & 27.748 .571 \\
\hline 4 & $\mathrm{D}$ & 15.290 .636 & $100,00 \%$ & 15.290 .636 \\
\hline 5 & $\mathrm{E}$ & 17.583 .354 & $100,00 \%$ & 17.583 .354 \\
\hline
\end{tabular}

Tabel. 7 Perhitungan Laba Kotor Konstruksi Tahun 2012 (dalam rupiah)

\begin{tabular}{|c|c|c|c|c|c|}
\hline No & $\begin{array}{c}\text { Nama } \\
\text { Proyek } \\
\text { Gedung }\end{array}$ & $\begin{array}{c}\text { Nilai } \\
\text { Kontrak } \\
\text { sebelum PPN }\end{array}$ & $\begin{array}{c}\text { Pendapatan } \\
\text { yang } \\
\text { Diakui }\end{array}$ & $\begin{array}{c}\text { Biaya Proyek } \\
\text { Berjalan } \\
\text { (Aktual) }\end{array}$ & $\begin{array}{c}\text { Laba Kotor } \\
\text { Konstruksi }\end{array}$ \\
\hline 1 & A & 29.322 .727 & 9.315 .830 & 8.993 .141 & 322.689 \\
\hline 2 & B & 31.032 .405 & 1.154 .405 & 1.041 .082 & 113.323 \\
\hline 3 & C & 27.748 .571 & 27.748 .571 & 24.546 .107 & 3.202 .464 \\
\hline 4 & D & 15.290 .636 & 15.290 .636 & 13.757 .605 & 1.533 .031 \\
\hline 5 & E & 17.583 .354 & 17.583 .354 & 15.744 .256 & 1.839 .098 \\
\hline
\end{tabular}

Dari tabel diatas, dapat dijelaskan bahwa: nilai kontrak sebelum PPN merupakan nilai kontrak bersih setelah dikurangi dengan PPN, RAB merupakan estimasi biaya yang akan dikeluarkan sampai dengan penyelesaian kontrak dan ditentukan di awal oleh perusahaan. Biaya proyek berjalan adalah total biaya aktual yang telah dikeluarkan untuk penyelesaian proyek pada periode tersebut. Persentase penyelesaian diperoleh dari perbandingan biaya aktual dengan RAB proyek selanjutnya dikalikan seratus persen. Pendapatan yang diakui dihitung 
dengan cara mengalikan persentase penyelesaian dengan nilai kontrak proyek. Sedangkan laba kotor merupakan selisih antara pendapatan yang diakui dengan biaya aktual yang terjadi.

\section{Perbandingan Antara Metode Pendekatan Physicall Progress dan Cost to Cost dalam Mengakui Pendapatan dan Laba Periode Berjalan}

Dari data tabel diatas dapat diketahui bahwa dengan menggunakan metode pendekatan cost to cost pendapatan yang diakui cenderung lebih rendah dibandingkan dengan menggunakan metode pendekatan physical progress. Perbedaan ini juga berpengaruh terhadap pengakuan laba kotor perusahaan, dimana dengan menggunakan metode cost to cost menunjukkan bahwa pengakuan laba kotor pun cenderung lebih rendah. Perbandingan pengakuan pendapatan dan laba kotor untuk periode tahun 2012 dapat dilihat pada tabel berikut:

Tabel.8 Rekapitulasi Perbandingan Perhitungan Pengakuan Pendapatan Metode Physical Progress dan Metode Pendekatan Cost to Cost (dalam rupiah)

\begin{tabular}{|l|l|l|l|}
\hline $\begin{array}{l}\text { Total } \\
\text { Proyek }\end{array}$ & Progres Fisik & Cost to Cost & $\begin{array}{l}\text { Selisih yang diakui } \\
\text { terlalu tinggi terlalu } \\
\text { rendah }\end{array}$ \\
\hline Jumlah & $575.368 .580 .500,73$ & $558.225 .441 .168,54$ & $17.143 .139 .332,19$ \\
\hline
\end{tabular}

Sumber: Data diolah

Tabel.9 Rekapitulasi Perbandingan Perhitungan Laba Kotor Metode Physical Progress dan Metode Pendekatan Cost to Cost (dalam rupiah)

\begin{tabular}{|l|l|l|l|}
\hline Proyek X & Progres Fisik & Cost to Cost & $\begin{array}{l}\text { Selisih yang diakui } \\
\text { terlalu tinggi terlalu } \\
\text { rendah }\end{array}$ \\
\hline Jumlah & $48.299 .095 .067,73$ & $31.155 .955 .735,54$ & $17.143 .139 .332,19$ \\
\hline
\end{tabular}

Sumber: Data diolah

Dari tabel diatas dapat diketahui bahwa terdapat selisih pengakuan pendapatan dan laba kotor yang diakui dengan menggunakan metode pendekatan physical progress dan cost to cost. Pendapatan dan laba yang diakui dengan pendekatan physical progress cenderung disajikan lebih tinggi (overstatement) karena hanya mengandalkan penilaian atau estimasi kemajuan fisik saja. Sedangkan pendapatan dan laba yang disajikan dengan pendekatan cost to cost lebih konservatif atau disajikan lebih rendah sesuai dengan proporsi biaya yang dikeluarkan dalam penyelesaian proyek tersebut, sehingga mencerminkan luas aktivitas pekerjaan serta kinerja yang sesungguhnya atas penyelesaian proyek dalam periode berjalan.

Pendekatan yang lebih sesuai untuk mengakui pendapatan dan laba proyek jangka panjang adalah dengan menggunakan metode pendekatan cost to cost karena melakukan pencatatan nilai pendapatan berdasarkan perhitungan proporsi 
biaya kontrak yang dikeluarkan. Hal ini sesuai dengan the matching principle yang menyatakan bahwa biaya yang dikeluarkan harus diakui dalam periode yang sama dengan pendapatan sebagai satu kesatuan, sehingga pendapatan dan laba kotor konstruksi diakui lebih tepat dalam rangka penyajian laporan keuangan yang wajar yang berguna untuk memberikan informasi lebih akurat dalam pengambilan keputusan.

\section{SIMPULAN DAN SARAN}

Berdasarkan hasil analisis dan penelitian, PT. Nolimax Jaya menerapkan metode persentase penyelesaian berdasarkan pendekatan physical progress dalam mengakui pendapatannya, dimana persentase penyelesaian dinilai berdasarkan estimasi kemajuan fisik atas pekerjaan yang telah dicapai di lapangan. Metode ini memiliki beberapa kelemahan, yaitu:

1. Taksiran penyelesaian kemajuan fisik yang dilakukan berdasarkan opname lapangan tidak menjamin keakuratan penilaian

2. Besarnya pendapatan yang diakui hanya didasarkan pada kemajuan fisik semata tanpa memperhatikan besarnya biaya yang terjadi

3. Biaya yang terjadi tidak dapat diatribusikan pada tahap penyelesaian pekerjaan proyek dalam mengakui pendapatan periode berjalan, yang menyebabkan pendapatan, beban, dan laba konstruksi yang dilaporkan tidak dapat diatribusikan menurut penyelesaian kontrak secara proporsional

Terdapat perbedaan yang signifikan dalam mengakui pendapatan dengan menggunakan metode pendekatan physical progress dan cost to cost, dimana dalam pendekatan fisik mengakui pendapatan dan laba lebih tinggi, sehingga menyebabkan pendapatan dan laba menjadi overstatement dalam penyajian laopran keuangan dan tidak sesuai dengan prinsip konservatisme dalam penyajian laporan keuangan. Perusahaan disarankan untuk menggunakan pendekatan cost to cost karena lebih memberikan gambaran yang wajar dalam mengakui pendapatan dan laba, dan memperhatiakan besarnya biaya yang terjadi atau yang telah dikeluarkan untuk tahap penyelesaian pekerjaan kontrak dalam periode berjalan, sehingga sesuai dengan konsep the matching principle dalam rangka penyajian laporan keuangan yang wajar.

\section{DAFTAR PUSTAKA}

Belkaoui, Ahmed Riahi. 2006. Teori Akutansi. Terjemahan. Edisi Kelima. Penerbit Salemba Empat. Jakarta.

Harahap, Sofyan Safri 2011, Teori Akuntansi, Edisi Revisi, Cetakan Kelima, PT. Raja Grafindo Perseda, Jakarta.

Ikatan Akuntan Indonesia. 2010. Standar Akuntansi Indonesia, Penerbit Salemba Empat, Jakarta. 
Ikatan Akuntan Indonesia. 2015. Pernyataan Standar Akuntansi Keuangan. Penerbit Ikatan Akuntan Indonesia. Jakarta.

Kieso, Weygandt, dan Warfield. 2007. Akuntansi Intermediate Edisi Keduabelas Jilid 2. Terjemahan. Erlangga. Jakarta.

Kieso, Donald E.,Weygant, Jerry J., Warfield, Terry D. 2010. Akuntansi Intermediate. Terjemahan. Edisi Kesepuluh. Penerbit Erlangga. Jakarta.

Krismiaji dan Anni, Aryani. 2011. Akuntansi Manajemen. Unit Penerbit dan Percetakan Sekolah Tinggi Ilmu Manajemen YKPN. Yogyakarta.

Mulyadi . 2005. Akuntansi Biaya. STIE, Yogyakarta.

Mulia, Budi. 2007. Pengakuan dan Pengukuran Pendapatan pada PT. Raya Utama Travel Medan. Universitas Airlangga. Surabaya.

Ratuman, Sisilia Marry. 2013. Analisis Pengakuan Pendapatan Dengan Persentase Penyelesaian Dalam Penyajian Laporan Keuangan PT. Pilar Dasar. Jurnal EMBA. Vol 1 No. 3. Juni. Hal 578-586. Universitas Sam Ratulangi. Manado

Rangkuti, Muhammad Ihsan 2008, Pengakuan dan Pengukuran Perusahaan Jasa Konstruksi Pada PT. Pembangunan Perumahan (Persero) Cabang I Medan, Usu e-Repisitory.

Rudianto, 2013. Akuntansi Manajemen, Penerbit Erlangga. Jakarta.

Skousen, Stice, 2009, Akuntansi Keuangan Intermidiate, Edisi Ke-16 Buku Satu, Terjemahan, Penerbit Salemba Empat, Jakarta.

Smith, Jay M. dan K. Fred Skousen 2006, Akuntansi Keuangan Menengah, Terjemahan, Penerbit Erlangga, Jakarta.

Supriyono R.A. 2011. Akuntansi Biaya Pengumpulan Biaya dan Penentuan Harga Pokok. Cetakan Kelima Belas. BPFE, Yogyakarta.

Sugiyono. 2014. Metode Penelitian Manajemen. Alfabeta: Bandung

Soemarso. 2005. Akuntansi Suatu Pengantar. Edisi Revisi, Salemba Empat, Jakarta. 